\title{
ILLEGAL IMPORT OF MOLLUSC SHELLS TO POLAND: SPECIES COMPOSITION AND TRADE ROUTES
}

\author{
ADAM WOJCIECHOWSKI
}

\begin{abstract}
Department of Environment Analysis, Institute of Geography and Regional Studies, Pomeranian
\end{abstract} University, 76-200 Słupsk, Partyzantów 27, Poland (e-mail: adam.wojciechowski@apsl.edu.pl)

ABSTRACT: This study analyses the volume of illegal import of mollusc shells to Poland, the source countries and the departure regions, based on the Polish Customs Service reports for 1998-2015. The records comprised 444 shell seizures including giant clams (Tridacnidae spp.), queen conch (Strombus gigas), unionids (Unionidae spp.), South African abalone (Haliotis midae) and souvenirs made from mollusc shells. The seized and confiscated shells came from 73 countries from five regions of the world: East and Southeast Asia (mainly the Philippines, Malaysia and Indonesia), Wider Caribbean (mainly the Bahamas and the USA), the Red Sea, the Indian Ocean and the Western Pacific. Three groups of perpetrators were involved in illegal shell trade: tourists smuggling mainly shells of $S$. gigas, small-scale illegal traders importing similar numbers of queen conch and giant clam shells, and legal traders involved in illegal trade and/or criminal organisations smuggling mainly tridacnid shells as well as souvenirs made from mollusc shells.

KEY WORDS: mollusc shells, CITES, illegal import, Poland

\section{INTRODUCTION}

Mollusc shells, especially marine, have always been an object of human interest (GösSLING et al. 2004, DIAS et al. 2011). Since the beginning of human culture, they have been used as tools, raw materials for industries, jewellery, currency, magical or religious symbols, as well as motifs in architecture, sculpture and paintings (SAMEK 1992, CLAASSEN 1998, GÖSSLING et al. 2004, VENKATESAN 2010, DiAS et al. 2011).

Due to their size, varied morphology, attractive colours and ornamentation, shells are extremely popular souvenirs and are often purchased or collected as 'portable memories' (GÖsSLING et al. 2004, NIJMAN \& LEE 2016). In the global trade, they are also offered as parts of decorative, utilitarian or non-utilitarian artefacts, and even as contemplative items (WOOD \& WELLS 1995, DiAs et al. 2011).

The intensive shell trade, observed in recent decades, results from the development of tourism in tropical countries and from the increase in online shopping (GÖSSLING et al. 2004, EUROPEAN COMMISSION 2006) thus contributing to excessive exploitation of the marine environment and significant decrease in populations of many species (BROAD et al. 2003). It is estimated that the global shell trade involves 5,000 species, mostly marine (WOOD \& Wells 1995). In south-east Brazil only, 126 mollusc species (10.2\% of them endemic) have been identified as items for sale as tourist products or incorporated in other tourist souvenirs (DIAS et al. 2011). Similarly, in retail trade in Florida there are about 300 species (WOOD \& WELLS 1995), with the most popular marine gastropods such as queen conch (Strombus gigas), tiger cowries (Cypraea tigris), helmet shells (Cassidae spp.), volutes (Volutidae spp.), and cones (Conidae spp.) (DIAS et al. 2011). Numerous studies document a large-scale shell trade in other parts of the world, i.a. Zanzibar (GÖssLING et al. 2004), South Indian Tamil Nadu state (JOHN et al. 2012), Hainan island (LARSON 2016), Indonesian islands of Java (NIJMAN et al. 2015) and Bali (NIJMAN \& LEE 2016), which involves tens of thousands of protected species such as giant clams (Tridacna spp.), horned helmet (Cassis cornuta), chambered nautilus (Nautilus pompilius), 
commercial top shell (Trochus niloticus), and marbled turban (Turbo marmoratus) (NIJMAN et al. 2015).

According to the statistics on international trade, the biggest shell exporters are Southeast Asian countries, especially Indonesia and the Philippines which sell at least 1,000 mollusc species (WOOD \& WELLS 1995, Rosen \& SMITH 2010, VAN UHM 2016). This region has also the biggest shell-craft industries and uses thousands of tons of molluscs per year for mother-of-pearl products (VENKATESAN 2010).

The Convention on International Trade in Endangered Species of Wild Fauna and Flora (CITES), which came into force in 1973, is designed to "protect endangered species [...] from over-exploitation by regulating or prohibiting their international trade" (CITES 1973). This Convention includes three appendices listing the species in which trade is legally regulated depending on their biological status and on how seriously they are threatened with extinction. Appendix I lists species that are threatened with extinction and trading in them is closely under control but allowed under exceptional circumstances. Appendix II includes species that are not necessarily threatened with extinction but trade in them should be subject to special regulations. Appendix III lists species subject to regulation within a particular member country.

The present list of molluscs protected under the Washington Convention (CITES 2017) includes Lithophaga lithophaga (Appendix II), Unionidae spp. (29 species, 26 of them listed in Appendix I and 3 in Appendix II), Tridacnidae spp. (Appendix II), Nautilidae spp. (Appendix II; since 2. January 2017), Strombus gigas (Appendix II), Achatinella spp. (Appendix I), Papustyla pulcherrima (Appendix II) and Polymita spp. (Appendix I; since 2. January 2017).

\section{MATERIAL AND METHODS}

Data for the analysis come from annual reports by the Polish Customs Service from 1998-2015 (ZATRZYMANIA CITES 1998-2015) introduced in accordance with the guidelines of the COUNCIL REGULATION (1997). They contain detailed information concerning the smuggled species, the number of specimens, the country of departure and the exact date and place of seizure. However, the quality of the data depends on the accuracy of records made by the customs services (see also BLUNDELL \& MASCIA 2005, VAN UHM 2016). It concerns the country of departure of the smuggled species and its correct labelling. In some cases, the reports of the customs services only indicate the source region (e.g. Africa, the Caribbean) or general name of the overseas territory (e.g. the Netherlands Antilles), which makes an accurate analysis of the trade direc-
The European Union incorporated the CITES regulations into the legal system by Regulation No. $3626 / 1982$ which entered into force on January 1st 1984 (COUNCIL REgULATION 1982). Council Regulation (EC) No. 338/97 of December 9th 1996 is the main legal act mandatory in the European Union regulating the trade in animal and plant species threatened with extinction (COUNCIL REGULATION 1997). Unlike in the CITES, there are four, not three, Annexes (A-D) listing the species that should be subject to special regulations. Annexes A, B and C list more or less the same species as the CITES, however, Annex D lists species from Appendix III CITES and also species not listed in the CITES which are imported to the EU in quantities that require monitoring. Trade in those species is allowed with notice of intent to import (COMMISSION REGULATION 2006).

The most important change implemented by later regulations of the committee (EC) is expanding the number of specimens of selected species whose export and import do not require permits. That includes, among other items, "shells of Strombus gigas, up to three per person" (COMMISSION REGULATION 2006, article 57.5d) and "shells of Tridacnidae spp. up to three specimens per person not exceeding three $\mathrm{kg}$ in total, where a specimen may be one intact shell or two matching halves" (COMMISSION REGULATION 2008, article 57.5f). In the above mentioned cases, it is allowed to transport up to three shells of $S$. gigas per person (since May 2006) and three tridacnid shells (since February 2008), whereas transporting more specimens of the listed species than stated in the regulations is regarded as smuggling. Those numbers are reflected in the numbers of specimens illegally imported to Poland.

tion impossible. In the case of giant clams, fully protected by the Washington Convention, the reports of the customs services often give the name of the family (Tridacnidae spp.) or genus (Tridacna spp.) only, which renders a detailed analysis of the smuggled species difficult.

In the article, the classification of the species follows the CITES (2017). This particularly concerns the giant clams which belong to the family Tridacnidae according to the Washington Convention, whereas according to the modern division, they constitute a subfamily Tridacninae within the family Cardiidae (HernaWAN 2012, NeO \& TODD 2012, PENNY 2012, NEO et al. 2015).

In accordance with the Washington Convention (CITES 2017), the abbreviation "spp." is here used to denote all species of a higher taxon. 


\section{RESULTS}

In 1998-2015, the Polish customs made 2,699 seizures of specimens of wild fauna and flora including 444 seizures of mollusc shells and souvenirs made from shells, which constituted $16.5 \%$ of all instances of illegal import. Most seizures of molluscs occurred in 2001-2007 (Fig. 1) when 382 (86\%) seizures of shells were made. Since 2008, the number of mollusc seizures decreased significantly and ranged from zero in 2013 to 11 in 2010 and 2012 (5.7\% and $7.6 \%$ respectively). However, the smaller number of seizures does not mean that there is less interest in mollusc shells, or that the market is saturated as it does not mean that the import has decreased. The phenomenon was affected by the regulations of the European Commission (COMMISSION REGULATION 2006, 2008) which recognised the import of up to three queen conch and giant clam shells per person as legal.

In the period under study, 1,701 mollusc shells including 1,114 giant clam (Tridacnidae spp.) shells, 566 queen conch (S. gigas) shells, seven unionid (Unionidae spp.) shells, 14 shells of South African

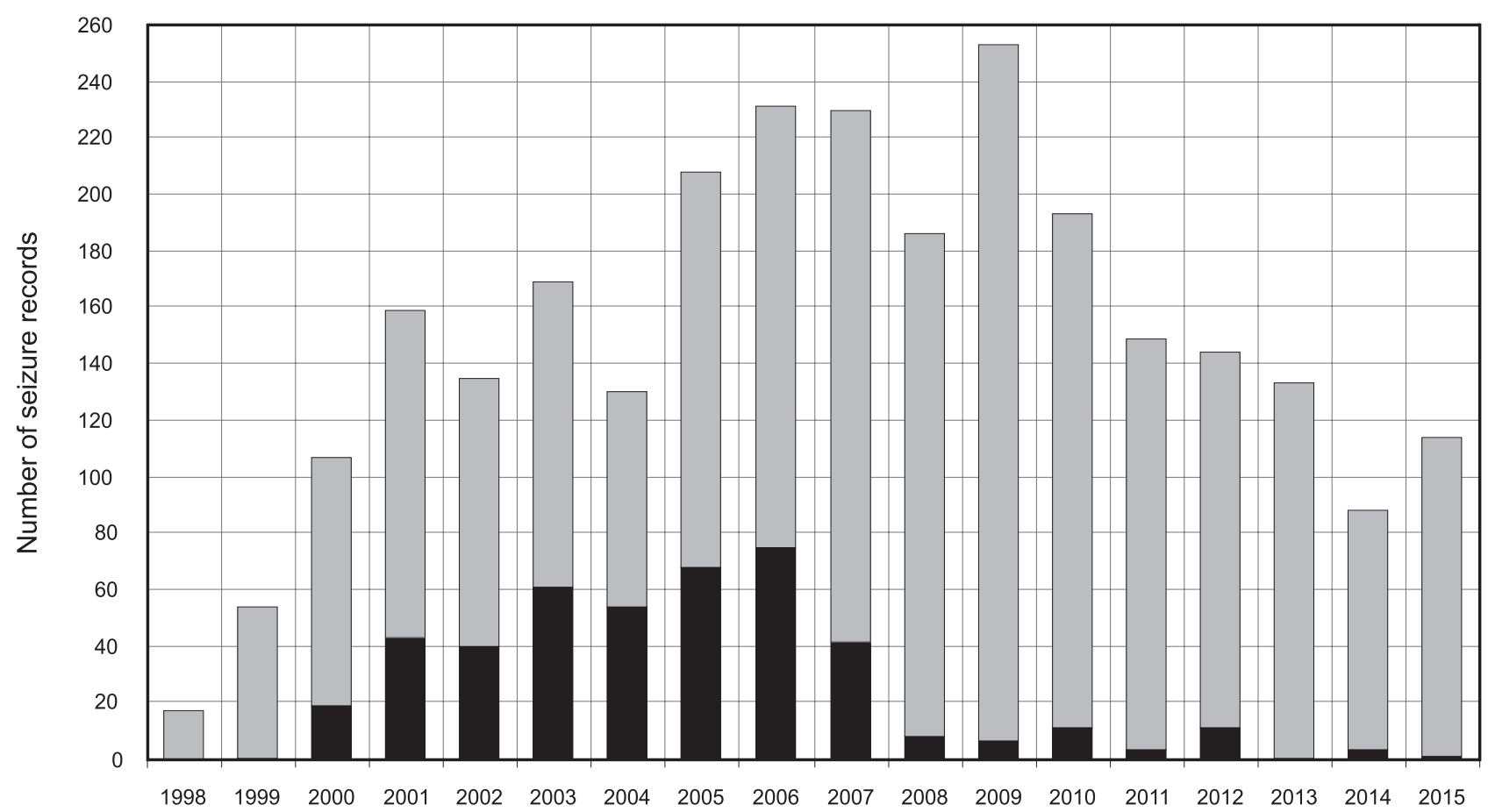

Fig. 1. Seizures of mollusc shells (black) compared to all seizures of wild fauna and flora specimens (grey) in 1998-2015

Table 1. List of mollusc taxa seized and confiscated by the Polish Customs Service in 1998-2015

\begin{tabular}{|c|c|c|c|c|c|c|}
\hline \multirow{2}{*}{ No } & \multirow{2}{*}{ Taxon } & \multirow{2}{*}{$\begin{array}{c}\text { Annex EU/ } \\
\text { Appendix CITES }\end{array}$} & \multicolumn{2}{|c|}{ Shells } & \multicolumn{2}{|c|}{ Seizures } \\
\hline & & & No & $\%$ & No & $\%$ \\
\hline 1 & Unionids (Unionidae spp.) & A-B/I-II & 7 & 0.41 & 1 & 0.23 \\
\hline 2 & Bear paw clam (Hippopus hippopus (Linnaeus, 1758)) & B/II & 6 & 0.35 & 4 & 0.91 \\
\hline 3 & China clam (Hippopus porcellanus Rosewater, 1982) & $\mathrm{B} / \mathrm{II}$ & 637 & 37.45 & 3 & 0.68 \\
\hline 4 & Boring clam (Tridacna crocea Lamarck, 1819) & B/II & 2 & 0.12 & 2 & 0.45 \\
\hline 5 & Southern giant clam (Tridacna derasa (Röding, 1798)) & B/II & 15 & 0.88 & 7 & 1.59 \\
\hline 6 & Giant clam (Tridacna gigas (Linnaeus, 1758)) & $\mathrm{B} / \mathrm{II}$ & 1 & 0.06 & 1 & 0.23 \\
\hline 7 & Small giant clam (Tridacna maxima (Röding, 1798)) & $\mathrm{B} / \mathrm{II}$ & 30 & 1.76 & 9 & 2.04 \\
\hline 8 & Fluted giant clam (Tridacna squamosa Lamarck, 1819) & B/II & 13 & 0.76 & 3 & 0.68 \\
\hline 9 & Giant clams (Tridacna spp.) & $\mathrm{B} / \mathrm{II}$ & 2 & 0.12 & 2 & 0.45 \\
\hline 10 & Giant clams (Tridacnidae spp.) & $\mathrm{B} / \mathrm{II}$ & $408^{1,2}$ & 23.99 & 121 & 27.44 \\
\hline 11 & Queen conch (Strombus gigas Linnaeus, 1758) & $\mathrm{B} / \mathrm{II}$ & 566 & 33.27 & 287 & 65.08 \\
\hline \multirow[t]{2}{*}{12} & South African abalone (Haliotis midae Linnaeus, 1758) & $\mathrm{D} /-$ & 14 & 0.82 & 1 & 0.23 \\
\hline & Total shells & & 1,701 & 100.00 & 441 & 100.00 \\
\hline 13 & Shell crafts & $\mathrm{B} / \mathrm{II}$ & 8,511 & 100.00 & 3 & 100.00 \\
\hline
\end{tabular}

${ }^{1}$ one live specimen included; ${ }^{2}$ one specimen of $42 \mathrm{~kg}$ brought from Indonesia in 2010. 
abalone (Haliotis midae) and 8,511 souvenirs made from mollusc shells were illegally brought to Poland. The total number of specimens was 10,212 (Table 1). Giant clam and queen conch shells prevailed among the confiscated goods and constituted $95 \%$ of all the seizure records.

\section{UNIONIDS (UNIONIDAE SPP.)}

Smuggling of unionids was an individual case and concerned the transit of seven shells of undetermined species from Russia to France in 2001. According to 2001 customs service documents (ZATRZYMANIA CITES 1998-2015), four shells of S. gigas and 34 coral skeletons: Acropora spp. (17 specimens), Antipatharia spp. (4), Euphyllia spp. (1), Platygyra spp. (1), Stylophora spp. (10), Tubiporidae spp. (1) and five sperm whale (Physeter macrocephalus) tusks were seized together with the unionid shells.

\section{GIANT CLAMS (TRIDACNIDAE SPP.)}

Giant clams are iconic and conspicuous inhabitants of coral reefs across the Indo-Pacific region (PENNY 2012). Presently, they occur in the area between South Africa, the Red Sea, Japan, Polynesia (except New Zealand and Hawaii) and Australia (BIN OTHMAN et al. 2010, NEO et al. 2015).

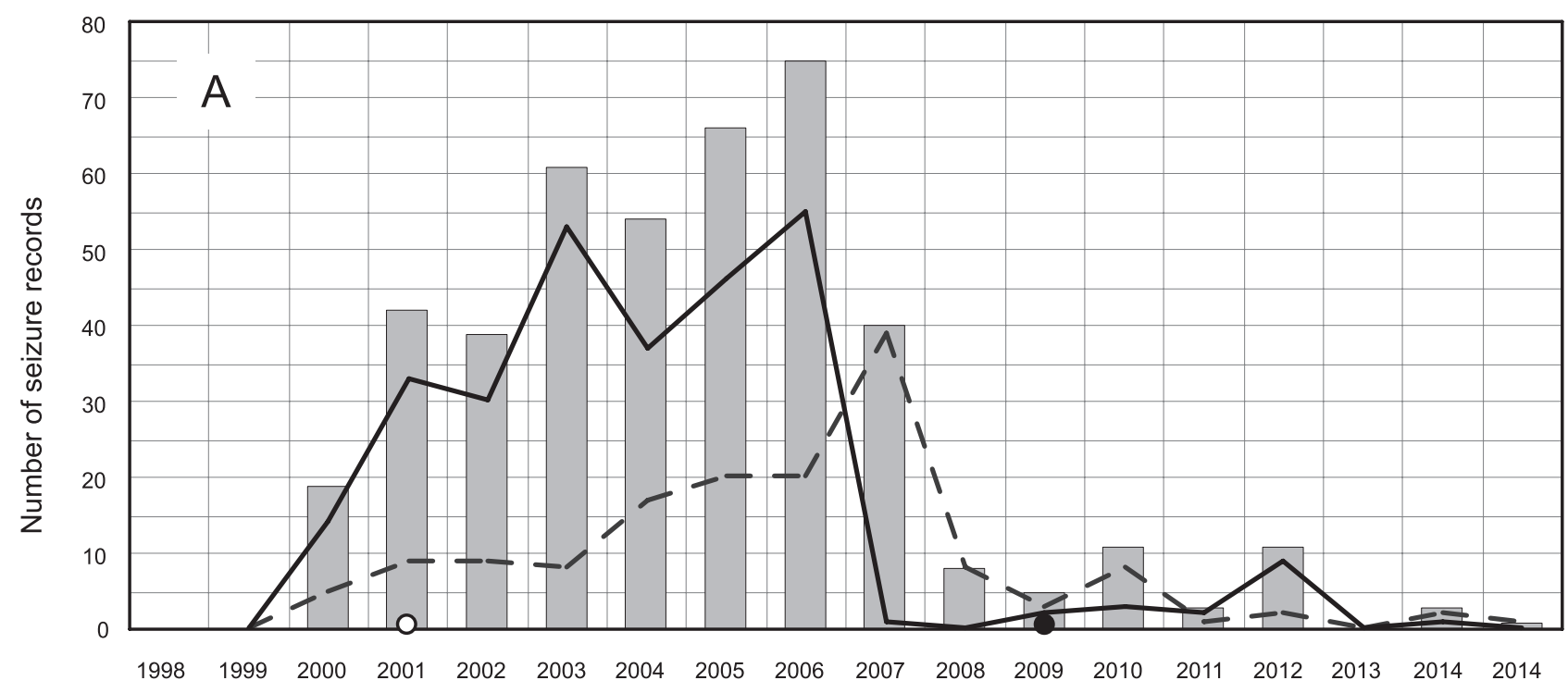

748 shells; 684 Tridacnidae spp.

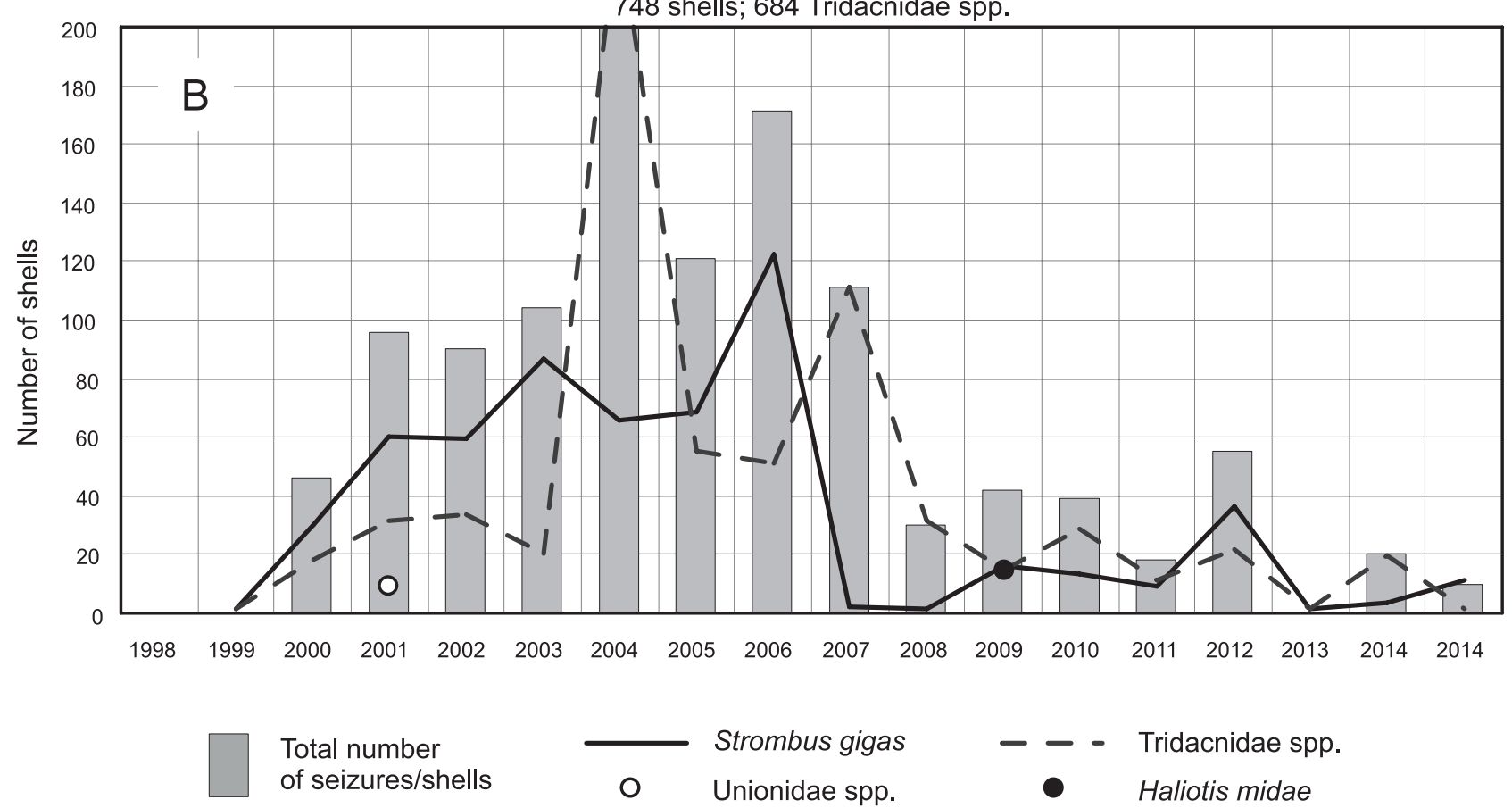

Fig. 2. A - Seizures of mollusc shells in 1998-2015, B - number of confiscated mollusc shells in 1998-2015 
They include only two genera, Hippopus and Tridacna, which comprise 13 species: $H$. hippopus, $H$. porcellanus, T. gigas, T. derasa, T. squamosa, T. noae (separated from T. maxima), T. maxima, T. crocea, T. mbalavuana (previously known as T. tevoroa), T. squamosina (previously known as $T$. costata), T. rosewateri, T. ningaloo and an undescribed cryptic Tridacna sp. (SOO \& TODD 2014). In 1983, the giant clam (T. gigas) and the southern giant clam (T. derasa) were listed in Appendix II of the CITES because of severe depletion of their populations. The other species of Tridacnidae were listed in Appendix II in 1985 because of their external similarity to the threatened species (SANT 1995). The shells are used as ornaments in the curio trade, troughs for holding water or feeding livestock and as garden decorations. Small live clams are also sold in the aquarium trade (SANT 1995).

A great interest in giant clam shells is observed among Polish importers. In 1998-2015, the customs services made 152 seizures of giant clams altogether and they confiscated 1,114 shells of Tridacnidae including 643 shells of Hippopus and 471 shells of Tridacna. Most of the seizures were made in 20042007 when from 17 to 39 attempts at illegal import of giant clams to Poland were recorded (Fig. 2A). In this period, 898 shells ( $80 \%$ of all giant clams), including 684 shells in 2004 and 110 in 2007, were imported illegally (Fig. 2B). Since 2008, the customs services made only a few seizures a year, with the greatest numbers in 2008 and 2010, when 10-30 shells were confiscated a year. The significant decrease in seizures results from the regulations of the European Commission which recognised the import of up to three giant clam shells per person as legal (COMMISSION REGULATION 2008).

There are four main source areas in the structure of trade routes: East and Southeast Asia, the Red Sea region, the Indian Ocean (mostly east African countries) and the Western Pacific (Table 2). Giant clam shells were most often brought from Egypt (20 seizures), Indonesia and Thailand (13 seizures each), Tanzania and Malaysia (8 seizures each) and the Philippines ( 7 seizures), which reflects the main destinations for the Polish tourist travels.

Moreover, giant clam shells were brought from outside the natural range of occurrence of Tridacnidae, most of them from Haiti (41 shells), the USA (6) and Ukraine (5).

\section{QUEEN CONCH (STROMBUS GIGAS)}

The queen conch is distributed throughout the tropical north-western Atlantic including Bermuda, the Florida Keys, the Greater and Lesser Antilles and the Caribbean coasts of Central and South America, south of Brazil and as far as the Gulf of
Table 2. Number of seizures and number of illegally imported shells of giant clams (Tridacnidae spp.) according to the countries of departure

\begin{tabular}{|c|c|c|c|c|c|}
\hline \multirow{2}{*}{ No } & \multirow{2}{*}{ Country of departure } & \multicolumn{2}{|c|}{ Shells } & \multicolumn{2}{|c|}{ Seizures } \\
\hline & & No & $\%$ & No & $\%$ \\
\hline \multicolumn{2}{|c|}{ East \& Southeast Asia } & 839 & 75.31 & 53 & 34.87 \\
\hline \multicolumn{2}{|c|}{1 Philippines } & 669 & 60.05 & 7 & 4.61 \\
\hline \multicolumn{2}{|c|}{2 Malaysia } & 57 & 5.12 & 8 & 5.26 \\
\hline \multicolumn{2}{|c|}{3 Indonesia } & 41 & 3.68 & 13 & 8.55 \\
\hline \multicolumn{2}{|c|}{4 Singapore } & 34 & 3.05 & 5 & 3.29 \\
\hline \multicolumn{2}{|c|}{5 Thailand } & 21 & 1.89 & 13 & 8.55 \\
\hline \multicolumn{2}{|c|}{6 China } & 6 & 0.54 & 2 & 1.32 \\
\hline \multicolumn{2}{|c|}{7 Vietnam } & 5 & 0.45 & 3 & 1.97 \\
\hline \multicolumn{2}{|c|}{8 Hong Kong } & 4 & 0.36 & 1 & 0.66 \\
\hline \multicolumn{2}{|c|}{9 Japan } & 2 & 0.18 & 1 & 0.66 \\
\hline \multicolumn{2}{|c|}{ Red Sea } & 76 & 6.82 & 24 & 15.79 \\
\hline \multicolumn{2}{|c|}{1 Egypt } & 53 & 4.76 & 20 & 13.16 \\
\hline \multicolumn{2}{|c|}{2 Saudi Arabia } & 22 & 1.97 & 3 & 1.97 \\
\hline \multicolumn{2}{|c|}{3 Israel } & 1 & 0.09 & 1 & 0.66 \\
\hline \multicolumn{2}{|c|}{ Indian Ocean } & 75 & 6.73 & 30 & 19.74 \\
\hline \multicolumn{2}{|c|}{1 Tanzania } & 21 & 1.89 & 8 & 5.26 \\
\hline 2 & Republic of South Africa & 14 & 1.26 & 4 & 2.63 \\
\hline 3 & Mauritius & 10 & 0.90 & 6 & 3.95 \\
\hline 4 & Seychelles & 10 & 0.90 & 3 & 1.97 \\
\hline 5 & Kenya & 6 & 0.54 & 4 & 2.63 \\
\hline 6 & India & 6 & 0.54 & 1 & 0.66 \\
\hline 7 & Africa & 2 & 0.18 & 1 & 0.66 \\
\hline 8 & Madagascar & 2 & 0.18 & 1 & 0.66 \\
\hline 9 & Mozambique & 2 & 0.18 & 1 & 0.66 \\
\hline 10 & Zimbabwe & 2 & 0.18 & 1 & 0.66 \\
\hline Paci & fic Ocean & 51 & 4.58 & 20 & 13.16 \\
\hline 1 & New Zealand & 11 & 0.99 & 1 & 0.66 \\
\hline 2 & Australia & 10 & 0.90 & 6 & 3.95 \\
\hline 3 & Vanuatu & 8 & 0.72 & 1 & 0.66 \\
\hline 4 & French Polynesia & 7 & 0.63 & 5 & 3.29 \\
\hline 5 & Papua New Guinea & 5 & 0.45 & 3 & 1.97 \\
\hline 6 & New Caledonia & 4 & 0.36 & 1 & 0.66 \\
\hline 7 & Palau & 3 & 0.27 & 1 & 0.66 \\
\hline 8 & Fiji Islands & 2 & 0.18 & 1 & 0.66 \\
\hline 9 & Tonga Islands & 1 & 0.09 & 1 & 0.66 \\
\hline Oth & er countries & 73 & 6.55 & 25 & 16.45 \\
\hline 1 & Haiti & 41 & 3.68 & 5 & 3.29 \\
\hline 2 & USA & 6 & 0.54 & 5 & 3.29 \\
\hline 3 & Ukraine & 5 & 0.45 & 2 & 1.32 \\
\hline 4 & Chile & 4 & 0.36 & 1 & 0.66 \\
\hline 5 & Greece & 2 & 0.18 & 2 & 1.32 \\
\hline 6 & Costa Rica & 2 & 0.18 & 1 & 0.66 \\
\hline 7 & Russia & 2 & 0.18 & 1 & 0.66 \\
\hline 8 & Austria & 1 & 0.09 & 1 & 0.66 \\
\hline 9 & Brazil & 1 & 0.09 & 1 & 0.66 \\
\hline 10 & Cyprus & 1 & 0.09 & 1 & 0.66 \\
\hline 11 & Denmark & 1 & 0.09 & 1 & 0.66 \\
\hline 12 & Germany & $1^{*}$ & 0.09 & 1 & 0.66 \\
\hline 13 & Undefined & 1 & 0.09 & 1 & 0.66 \\
\hline 14 & Internal seizures & 5 & 0.45 & 2 & 1.32 \\
\hline & Total & 1,114 & 100.00 & 152 & 100.00 \\
\hline
\end{tabular}

*one live specimen of Tridacnidae spp. 
Table 3. Number of seizures and number of illegally imported shells of queen conch (Strombus gigas) according to the countries of departure

\begin{tabular}{|c|c|c|c|c|c|}
\hline \multirow{2}{*}{ No } & \multirow{2}{*}{ Country of departure } & \multicolumn{2}{|c|}{ Shells } & \multicolumn{2}{|c|}{ Seizures } \\
\hline & & No & $\%$ & No & $\%$ \\
\hline \multicolumn{2}{|c|}{ Wider Carribean } & 513 & 90.64 & 260 & 90.59 \\
\hline 1 & The Bahamas & 125 & 22.08 & 59 & 20.56 \\
\hline 2 & USA & 123 & 21.73 & 74 & 25.78 \\
\hline 3 & Dominican Republic & 67 & 11.84 & 40 & 13.94 \\
\hline 4 & Cuba & 51 & 9.01 & 13 & 4.53 \\
\hline 5 & Mexico & 30 & 5.30 & 22 & 7.67 \\
\hline 6 & Haiti & 26 & 4.59 & 7 & 2.44 \\
\hline 7 & Honduras & 14 & 2.47 & 6 & 2.09 \\
\hline 8 & Jamaica & 14 & 2.47 & 4 & 1.39 \\
\hline 9 & Barbados & 10 & 1.77 & 5 & 1.74 \\
\hline 10 & Colombia & 8 & 1.41 & 6 & 2.09 \\
\hline 11 & Carribean & 8 & 1.41 & 2 & 0.70 \\
\hline 12 & Brazil & 7 & 1.24 & 3 & 1.05 \\
\hline 13 & Grenada & 5 & 0.88 & 2 & 0.70 \\
\hline 14 & Anguilla & 4 & 0.71 & 1 & 0.35 \\
\hline 15 & Venezuela & 3 & 0.53 & 2 & 0.70 \\
\hline 16 & Martinique & 3 & 0.53 & 1 & 0.35 \\
\hline 17 & Puerto Rico & 3 & 0.53 & 1 & 0.35 \\
\hline 18 & Antigua \& Barbuda & 2 & 0.35 & 2 & 0.70 \\
\hline 19 & Aruba & 2 & 0.35 & 2 & 0.70 \\
\hline 20 & Cayman Islands & 2 & 0.35 & 2 & 0.70 \\
\hline 21 & Netherlands Antilles & 2 & 0.35 & 2 & 0.70 \\
\hline 22 & Curaçao & 1 & 0.18 & 1 & 0.35 \\
\hline 23 & Panama & 1 & 0.18 & 1 & 0.35 \\
\hline 24 & Trinidad \& Tobago & 1 & 0.18 & 1 & 0.35 \\
\hline 25 & Turks \& Caicos Islands & 1 & 0.18 & 1 & 0.35 \\
\hline \multicolumn{2}{|c|}{ Other countries } & 53 & 9.36 & 27 & 9.41 \\
\hline \multicolumn{2}{|c|}{1 Kenya } & 8 & 1.41 & 2 & 0.70 \\
\hline \multicolumn{2}{|c|}{2 Russia } & 7 & 1.24 & 4 & 1.39 \\
\hline \multicolumn{2}{|c|}{3 Spain } & 5 & 0.88 & 4 & 1.39 \\
\hline \multicolumn{2}{|l|}{4} & 5 & 0.88 & 1 & 0.35 \\
\hline \multicolumn{2}{|c|}{5 Phil } & 5 & 0.88 & 1 & 0.35 \\
\hline \multicolumn{2}{|l|}{6} & 4 & 0.71 & 3 & 1.05 \\
\hline \multicolumn{2}{|r|}{ Khazakstan } & 3 & 0.53 & 2 & 0.70 \\
\hline \multirow{2}{*}{$\begin{array}{l}8 \\
9\end{array}$} & Canada & 2 & 0.35 & 1 & 0.35 \\
\hline & Denmark & 2 & 0.35 & 1 & 0.35 \\
\hline & Ghana & 2 & 0.35 & 1 & 0.35 \\
\hline 11 & Greece & 2 & 0.35 & 1 & 0.35 \\
\hline 1 & India & 2 & 0.35 & 1 & 0.35 \\
\hline 13 & United Arab Emirates & 2 & 0.35 & 1 & 0.35 \\
\hline 1 & Africa & 1 & 0.18 & 1 & 0.35 \\
\hline \multirow{2}{*}{$\begin{array}{l}1 \\
1\end{array}$} & Egypt & 1 & 0.18 & 1 & 0.35 \\
\hline & Thailand & 1 & 0.18 & 1 & 0.35 \\
\hline \multirow[t]{2}{*}{17} & Internal seizure & 1 & 0.18 & 1 & 0.35 \\
\hline & Total & 566 & 100.00 & 287 & 100.00 \\
\hline
\end{tabular}

Mexico (THeILE 2001, 2005). The species has been listed in Appendix II of the CITES since November 1992 (CITES SECRETARIAT 2003). The queen conch has been harvested for food for centuries, however, a large commercial fishery has developed only in the last few decades, mainly in response to the increased international demand for the meat. The shells are also used and traded as curio and tourist souvenirs (CITES SECRETARIAT 2003, THEILE 2005).

In 1998-2015, the Polish Customs Service made 287 seizures of queen conch shells including 260 seizures $(90.59 \%)$ from 25 countries of the Caribbean region and 27 seizures $(9.41 \%)$ from countries outside that region (Table 3). Most of the seizures of $S$. gigas were made in 2003-2006 when annually from 36 (2004) to 55 (2006) instances of illegal import were recorded (Fig. 2A). In 1998-2015, 566 shells were smuggled to Poland altogether, among which nearly 60\% (337 shells) were smuggled in 2003 2006 (Fig. 2B). Since 2007, the number of queen conch seizures significantly decreased and ranged from zero in 2008 and 2013 to nine in 2012, with subsequent decrease in the number of confiscated shells. The significant decrease in queen conch seizures results from the regulations of the European Commission which recognised the import of up to three shells per person as legal (COMMISSION REGULATION 2006).

Over $64 \%$ of all the queen conch shells were brought from four Caribbean countries (Table 3): the Bahamas (125 shells), the USA (123), the Dominican Republic (67) and Cuba (51). Besides, shells of $S$. gigas were brought from 17 countries outside the Caribbean region, most of them from Kenya (8) and Russia (7).

\section{SOUTH AFRICAN ABALONE (HALIOTIS MIDAE)}

The South African abalone is not listed by the CITES but it is included in Annex D of the European Commission Regulation (COMMISSION REGULATION 2006, 2008), which means that a notice of import to the EU is required. The Polish Customs Service made a single seizure of 14 shells of $H$. midae brought from the USA in 2009 without the required documents (ZATRZYMANIA CITES 1998-2015).

\section{SOUVENIRS MADE FROM SHELLS}

Apart from mollusc shells as such, on three occasions the customs services seized and confiscated souvenirs made from shells. There were 8,511 souvenirs altogether including 958 lamps made from giant clam shells brought from China in 2002, one souvenir made from three queen conch shells brought from Mexico in 2004, as well as 7,552 souvenirs made from mollusc shells (non-CITES species) and stony corals (Scleractinia spp.) smuggled from Vietnam in 2007 (ZATRZYMANIA CITES 19982015). 


\section{DISCUSSION}

Due to its location along the trade routes between the East and the West, Poland constitutes an important destination and transit point for illegal wildlife trade in Europe. According to the European Union Trade in Wildlife Information eXchange (EU-TWIX) database for 2001-2010 (VAN UHM 2016) Poland, with the 1,599 seizures, is the third country in the European Union after Germany (7,266 seizures) and the Netherlands (2,590 seizures) in respect of thwarted attempts at smuggling the CITES species. The analysis of the Polish Customs Service reports for 1998-2015 (ZATRZYMANIA CITES 1998-2015) shows that, in terms of the number of seizures (444), mollusc shells constituted the second biggest group of smuggled wildlife after corals (987 seizures), and were followed by prepared animals (430), traditional Asian medicaments (230), leather products (205), live animals (184), and other categories (219).

The scale of illegal import of shells and demand for them on the Polish market can be illustrated by comparing it to the legal import of shells to Poland which is at least thirty times smaller than the illegal import. In 2003-2015, only 17 shells of S. gigas and 325 live specimens of Tridacnidae spp. were brought to Poland legally, including $H$. hippopus (50 specimens), T. crocea (100), T. derasa (70), T. maxima (20) and T. squamosa (85). The queen conch shells were brought for private purposes from Turks \& Caicos (4 specimens in 2003), Cuba (8 in 2011) and Nicaragua (5 in 2015), whereas the giant clams were imported for commercial purposes from Malaysia (75 in 2004) and Indonesia (250 in 2007-2009) (data after SOBCZAK 2016).

According to the analysis of the customs service reports, the seizures of mollusc shells and souvenirs made from shells were most frequently made by the customs chamber in Gdynia (242 seizures) which operates in the big sea harbours (Gdańsk, Gdynia) and in the Lech Wałęsa Airport, as well as by the customs chamber in Warsaw (152 seizures) which controls the Warsaw Airport, the busiest in Poland. In 1998-2015, the two customs chambers made 394 seizures of molluscs altogether which constituted $88.7 \%$ of all shipments (Table 4 ). The greatest number of seizures in just those two places may indicate the existence of the most often selected smuggling routes. The statistics of the Polish customs services correspond to the EU-TWIX data (VAN UHM 2016) indicating that the main entry points for illegal wildlife import to the EU are large airports (e.g. Schiphol, Frankfurt, Heathrow) and the major sea ports (e.g. Antwerp, Hamburg, Rotterdam).

The analysis of seizures of molluscs by customs offices shows a clear asymmetry of imports (Table 4). Shells of S. gigas were most frequently confiscated in Gdynia (191 seizures) whereas those of Tridacnidae spp. were most often confiscated in Warsaw (80 seizures), which may be due to the transport network. The Warsaw Airport operates the greatest number of air connections with countries of the Far East, Southeast Africa and Australia and Oceania where the giant clams come from, while the sea ports of Gdynia and Gdańsk provide transport connections with the Caribbean and the USA where the queen conch comes from.

There are three major groups of perpetrators involved in illegal import of shells and souvenirs made from shells: a) tourists bringing from one to two shells per person b) small-scale illegal traders (3-15 shells) and c) legal traders involved in illegal trade and/or criminal organisation (over 15 shells) (EUROPEAN COMMISSION 2006, VAN UHM 2016).

Tourists often constitute an unaware but significant group of smugglers (Table 5). In 1998-2015, shell smuggling by tourists made the biggest part of seizures (334) and a relatively large number of imported shells (429 specimens). Tourists brought queen conch shells (68.5\%) more often than giant clam shells $(31.5 \%)$, which reflects a similar trend recorded in the EU (VAN UHM 2016). Small-scale illegal traders brought 560 shells altogether (102 seizures), among which giant clams $(52.5 \%)$ prevailed over the queen conch $(43,8 \%)$, whereas only seven seizures were recorded in the group of legal traders involved in illegal trade and/or criminal organisations: 712 shells were confiscated, most of them being giant clams $(96.2 \%)$, as well as 8,510 souvenirs made from shells (Table 5).

The spatial structure of shell import routes shows five major source areas comprising as many as 73 countries. The biggest of them is East and Southeast Asia from which 839 giant clam shells (75\% of all gi-

Table 4. Seizures of shells and souvenirs made from shells by the Polish Customs Chambers in 1998-2015

\begin{tabular}{lrrrrrr}
\hline \multirow{2}{*}{ Customs chamber } & \multicolumn{2}{c}{ Total seizures } & \multicolumn{2}{c}{ Seizures of Strombus gigas } & \multicolumn{2}{c}{ Seizures of Tridacnidae spp. } \\
\cline { 2 - 7 } & No & $\%$ & No & $\%$ & No & $\%$ \\
\hline Gdynia & 242 & 54.5 & 191 & 66.6 & 49 & 32.3 \\
Warsaw & 152 & 34.2 & 71 & 24.7 & 80 & 52.6 \\
9 others & 50 & 11.3 & 25 & 8.7 & 23 & 15.1 \\
\hline Total & 444 & 100.0 & 287 & 100.0 & 152 & 100.0 \\
\hline
\end{tabular}


Table 5. Volume of illegal import of mollusc shells and souvenirs made from shells by different groups of perpetrators

\begin{tabular}{|c|c|c|c|c|c|c|}
\hline \multirow[t]{2}{*}{ Category } & \multicolumn{2}{|c|}{$\begin{array}{c}\text { Tourists } \\
\text { (1-2 shells) }\end{array}$} & \multicolumn{2}{|c|}{$\begin{array}{l}\text { Small-scale illegal traders } \\
\quad(3-15 \text { shells })\end{array}$} & \multicolumn{2}{|c|}{$\begin{array}{l}\text { Legal traders involved in } \\
\text { illegal trade and/or criminal } \\
\text { organisations (over } 15 \text { shells) }\end{array}$} \\
\hline & specimens & seizures & specimens & seizures & specimens & seizures \\
\hline Strombus gigas & 294 & 234 & 245 & 52 & 27 & 1 \\
\hline Tridacnidae spp. & 135 & 100 & 294 & 48 & 685 & 4 \\
\hline Unionidae spp. & - & - & 7 & 1 & - & - \\
\hline Haliotis midae & - & - & 14 & 1 & - & - \\
\hline Shells & 429 & 334 & 560 & 102 & 712 & 5 \\
\hline Shell crafts & 1 & 1 & - & - & 8,510 & 2 \\
\hline Total & 430 & 335 & 560 & 102 & 9,222 & 7 \\
\hline
\end{tabular}

ant clams brought to Poland), six queen conch shells and 8,510 souvenirs made from mollusc shells were brought. The second most important source area is Wider Caribbean (25 countries), from which 90.6\% of all shells of S. gigas, 50 shells of Tridacnidae spp. and 14 shells of $H$. midae were brought. Seventy six giant clam shells and three queen conch shells were brought from the Red Sea area, mostly from Egypt and Saudi Arabia. Seventy five giant clam shells and 11 queen conch shells were brought from the Indian Ocean area (mostly from east African countries), while 51 shells, only giant clams, were brought from the Western Pacific.

In terms of the country of origin, most shells were brought from the Philippines (674), the USA (143), the Bahamas (125), the Dominican Republic (67), Malaysia (57), Egypt (54) and Cuba (51).

It is also noteworthy that a high proportion of shells is imported from regions other than their natural distribution range: the former Soviet Union (28 shells), the European Union (21) and other countries such as Canada, Chile, Ghana, Nigeria (14). This may indicate globalization of wildlife trade including mollusc shells. The phenomenon is also recognised in other regions of the world. DIAS et al. (2011), among others, indicate that the north-eastern Brazilian trade includes only $68 \%$ of species harvested from the Atlantic Ocean and $32 \%$ of the sold shells come from other regions, i.a. the Indo-Pacific, Western Europe and the Mediterranean.

\section{CONCLUSION}

The analysis of illegal import of mollusc shells to Poland reveals a large scale of smuggling and its global scope in which the source countries specialising in illegal trade play the most important role. It must be emphasised that the seizures reported by the customs service reflect only a fraction of the illegal trade, since a large part of the trade remains unreported or undiscovered, the so-called dark figure of crime (VAN UHM 2016). Law enforcement experts estimate that no more than 10 per cent of all contraband wildlife is seized (VAN UHM 2016), which means that the actual volume of illegal import to Poland is much bigger and concerns not only the species listed in the CITES but may also involve many other protected species of molluscs.

The distinct disproportion between legal and illegal shell trade where smuggling plays the dominant role means that the present legislation is ineffective and unsatisfactory. In the case of illegal trade in giant clams and queen conch shells, it seems that it was a

mistake to expand the number of specimens whose import and export does not require any permission (COMmission Regulation 2006, 2008). Such legislation is very likely to result in legal wildlife trade encouraging the illegal trade.

\section{ACKNOWLEDGEMENTS}

I am grateful to Mr KAROL WOLNICKI from the Conventions Department in the Ministry of the Environment in Warsaw for his help in verifying the seizure records of Tridacnidae spp. brought from Haiti. Thanks are also due to Mr ANDRZEJ ŚWISTOWSKI, the customs company officer and the CITES coordinator from the Customs Chamber in Gdynia for the discussion of certain issues connected with the customs service work, as well as to Prof. dr hab. BEATA M. POKRYSZKO for language correction, and to two anonymous reviewers for their valuable comments. 


\section{REFERENCES}

BIN Othman A. S., GoH G. H. S., TodD P. A. 2010. The distribution and status of giant clams (Family Tridacnidae) - a short review. Raffles Bull. Zool. 58: 103-111.

Blundell A. G., MASciA M. B. 2005. Discrepancies in reported levels of international wildlife trade. Conserv. Biol. 19: 2020-2025. https://doi.org/10.1111/j.15231739.2005.00253.x

Broad S., Mulliken T., RoE D. 2003. The nature and extent of legal and illegal trade in wildlife. In: OLDFIELD S. (ed.). The trade in wildlife: regulation for conservation. Earthscan Publication Ltd., London \& Sterling, VA, pp. 3-22.

CITES SECRETARIAT 2003. Review of significant trade in Strombus gigas, AC19 Doc. 8.3 In: Review of significant trade in specimens of Appendix-II species (Resolution Conf. 12.8 and Decision 12.75), Progress on the implementation of the review of significant trade (Phases IV and V). Nineteenth meeting of animals Committee Geneva (Switzerland), August 18-21, 2003: 1-71.

CITES (Convention on International Trade in Endangered Species of Wild Fauna and Flora) 1973. Text of the Convention. URL: https://www.cites.org/eng/disc/ text.php.

CITES (Convention on International Trade in Endangered Species of Wild Fauna and Flora) 2017. Appendices I, II and III. URL: https://www.cites.org/eng/app/appendices.php.

ClaAssen C. 1998. Shells. Cambridge University Press, Cambridge, UK.

COMMISSION REgUlATION (EC) 2006. No 865/2006 of 4 May 2006 laying down detailed rules concerning the implementation of Council Regulation (EC) No 338/97 on the protection of species of wild fauna and flora by regulating trade therein. URL: http://eur-lex.europa.eu/ legal-content/EN/ALL/?uri=CELEX\%3A32006R0865.

COMMISSION REgULATION (EC) 2008. No 100/2008 of 4 February 2008 amending, as regards sample collections and certain formalities relating to the trade in species of wild fauna and flora, Regulation (EC) No 865/2006 laying down detailed rules for the implementation of Council Regulation (EC) No 338/97. URL: http://eur-lex.europa.eu/legal-content/ EN/TXT/?uri = celex\%3A32008R0100.

CounCIL REgulATION (EC) 1997. No 338/97 of 9 December 1996 on the protection of species of wild fauna and flora by regulating trade therein. URL: http://eur-lex.europa. eu/legal-content/en/ALL/?uri=CELEX:31997R0338.

Council Regulation (EEC) 1982. No 3626/82 of 3 December 1982 on the implementation in the community of the Convention on International Trade in Endangered Species of Wild Fauna and Flora. URL: http://eur-lex.europa.eu/legal-content/LV/TXT/ ?uri=CELEX:31982R3626.

DiAs T. L., Neto N. A. L., Alves R. R. 2011. Molluscs in the marine curio and souvenir trade in NE Brazil: species composition and implications for their conservation and management. Biodivers. Conserv. 20: 2393-2405. https://doi.org/10.1007/s10531-011-9991-5
EUROPEAN COMMISSION 2006. Study on the enforcement of the EU Wildlife Trade Regulations in the EU-25. Milieu Consortium: 1-38.

GÖSSLING S., KUNKEL T., SCHUMACHER K., ZILGER M. 2004. Use of molluscs, fish, and other marine taxa by tourism in Zanzibar, Tanzania. Biodivers. Conserv. 13: 2623 2639. https://doi.org/10.1007/s10531-004-2139-0

HERNAWAN U. E. 2012. Taxonomy of Indonesian giant clams (Cardiidae, Tridacninae). Biodiversitas 13: 118123. https://doi.org/10.13057/biodiv/d130303

JOHN S., BATU M. P. K., Kuppusamy S., ChOUdhURY B. C. 2012. An assessment of marine fauna of Indian wildlife in Curio Trade. A market study from Tamil Nadu, South India. Int. J. Conserv. Sci. 3: 217-230.

LARSON C. 2016. Shell trade pushes giant clams to the brink. Science 351: 323-324. https://doi.org/10.1126/ science.351.6271.323

NEO M. L., ECKMAN W., VICENTUAN K., TEO S. L.-M., TODD P. A. 2015. The ecological significance of giant clams in coral reef ecosystems. Biol. Conserv. 181: 111-123. https://doi.org/10.1016/j.biocon.2014.11.004

NeO M. L., TODD P. A. 2012. Giant clams (Mollusca: Bivalvia: Tridacninae) in Singapore: history, research and conservation. Raffles Bull. Zool. Suppl. No. 25: 67-78.

NijMAN V., LEE P. B. 2016. Trade in nautilus and other large marine molluscs as ornaments and decorations in Bali, Indonesia. Raffles Bull. Zool. 64: 368-373.

NiJMAN V., SPAAN D., NEKARIS K.A.-I. 2015. Large-scale trade in legally protected marine mollusc shells from Java and Bali, Indonesia. PloS ONE 10: e0140593. https://doi.org/10.1371/journal.pone.0140593

PENNY S. 2012. Giant clams in the 'Top End'. Malacol. Soc. Austr. Newsl. 143: 1-3.

Rosen G. E., SMitH K. F. 2010. Summarizing the evidence on the international trade in illegal wildlife. EcoHealth 7: 24-32. https://doi.org/10.1007/s10393-010-0317-y

SAMEK A. 1992. Muszle morskie. Muzeum Przyrodnicze Instytutu Systematyki i Ewolucji Zwierząt PAN, Kraków.

SANT G. 1995. Marine invertebrates of the South Pacific: an examination of the trade. TRAFFIC International, United Kingdom.

SOBCZAK P. 2016. Struktura i kierunki importu gatunków fauny CITES do Polski w latach 2003-2015. Master's thesis, Zakład Analizy Środowiska, Akademia Pomorska w Słupsku.

SoO P., TODD P. A. 2014. The behaviour of giant clams (Bivalvia: Cardiidae: Tridacninae). Mar. Biol. 161: 26992717. https://doi.org/10.1007/s00227-014-2545-0

THEILE S. 2001. Queen conch fisheries and their management in the Caribbean. TRAFFIC Europe.

THEILE S. 2005. Status of the queen conch Strombus gigas Stocks. Management and trade in the Caribbean: A CITES Review. Proceedings of the 56th Annual Gulf and Caribbean Fisheries Institute: 675-694. 
VAN UHM D. 2016. Illegal wildlife trade to the EU and harms to the world. In: SPAPENS T., WHITE R., HUISMAN W. (eds). Environmental crime in transnational context: global issues in green enforcement and criminology. Routledge, London-New York, pp. 43-66.

VENKATESAN V. 2010. Marine ornamental molluscs. In: National Training Programme on Marine Fish Culture, CMFRI, Mandapam, pp. 27-32.

WoOD E., Wells S. M. 1995. The shell trade: a case for sustainable utilization, In: KAY E. A. (ed.). The conservation biology of mollusc. Occasional Paper of the IUCN Species Survival Commission No 9, IUCN, Cambridge, pp. 41-52.

ZATRZYMANIA CITES dokonane przez Służbę Celną, 1998-2015 [Seizures of CITES specimens made by the Polish Customs Service, 1998-2015]. Wydział Ograniczeń Pozataryfowych, Departament Polityki Celnej, Ministerstwo Finansów, Warszawa.

Received: July 10th, 2017 Revised: August 16th, 2017 Accepted: September 1st, 2017 Published on-line: October 31st, 2017 